\title{
The dependence on protein quality of the protein to calorie ratio in a freely selected diet and the usefulness of giving protein and calories separately in protein evaluation experiments
}

\author{
By G. POL AND C. DEN HARTOG \\ Netherlands Institute of Nutrition, Wageningen, Holland
}

(Received 9 August 1965-Accepted 25 April 1966)

\begin{abstract}
I. Concentrated protein diets $(60 \%)$ were prepared with potato protein and wheat gluten. At two different feeding levels and on an ad lib. scale, these diets were given separately from a protein-free diet (supplied ad lib.) to six groups of rats. 2. The relationship between bodyweight and total calorie intake was confirmed and the regression equation was calculated. 3. The rat possesses a regulating mechanism controlling the intake of the non-protein calories needed for any limited or free protein intake. The intake of non-protein calories is completely determined by the nitrogen retention and hence by the quality and quantity of the protein. This holds true for any dietary protein level. On a high-quality protein (potato) and on a lowquality protein (gluten) rats can reach the same optimal weight gain when they are allowed to choose the calorie: protein ratio spontaneously. Under these conditions food efficiency ratios and the utilization of calories for growth are also optimal and almost the same for both groups. To attain this far more gluten is needed than potato protein, whereas the number of total calories consumed is similar.
\end{abstract}

In I96I some remarkable observations were made by Jacquot and his colleagues at the Centre de Recherches sur la Nutrition, Bellevue, France (Abraham, Calet, Rerat \& Jacquot, I96r ; Calet, Jouandet \& Baratou, I96I). It was found that, when proteins and calories were given separately, the chicken and the rat were able to select spontaneously a fixed calorie: protein ratio. This ratio seemed to be characteristic for the protein; i.e. the ratio increased with increasing biological value of the protein. Special attention was drawn to these observations by Bigwood (1965) in his contribution to the Symposium of the Group of European Nutritionists held in Wageningen in 1964 . In further studies this finding has been used to develop a new method for the evaluation of proteins, the protein and the non-protein constituents of the diet being given separately (Rerat $\&$ Henry, I963; Abraham \& Peretianu, 1963). The method is based on their conclusions that food intakes are regulated by energy requirements, the latter being a function of body-weight on the one hand and of the quantity and the biological value of the protein on the other hand. In the assay technique fixed quantities of the protein are given and the non-protein components are supplied $a d$ lib.; the authors also studied the effect of supplying both the proteins and the calories ad lib. With protein given ad lib. they found no relationship between the quantity of protein spontaneously consumed and the requirements for maximum growth, whereas on restricted protein feeding the ratio of calories to protein was determined by the protein retention. As it is claimed that the method for evaluating the protein efficiency ratio (PER) introduced by Abraham \& Peretianu (1963) yields a smaller variance and consequently permits 
sharper differentiation between different proteins than the classical assay, it was decided to study the method with two different proteins and under varying experimental conditions.

\section{EXPERIMENTAL}

The proteins to be tested were potato protein and wheat gluten. Both were commercial products containing $12 \cdot 1 \mathrm{I}$ and $13 \cdot 15 \%$ of nitrogen respectively. The animals refused to eat these protein concentrates, and so they were diluted with an adequate amount of the sweet-tasting protein-free diet, rich in vitamins.

Table I. Composition of the protein-free diet (ingredients/I kg diet)

\begin{tabular}{|c|c|c|c|}
\hline Ingredient & Amount & Ingredient & Amount \\
\hline Sucrose & $875 \mathrm{~g}$ & $\mathrm{CaHPO}_{4} \cdot 2 \mathrm{H}_{2} \mathrm{O}$ & $16.9 \mathrm{~g}$ \\
\hline Maize oil & $80 \mathrm{~g}$ & $\mathrm{KCl}$ & $8 \cdot 7 \mathrm{~g}$ \\
\hline \multirow[t]{2}{*}{ Cellulose } & $30 \mathrm{~g}$ & $\mathrm{NaCl}$ & $3 \cdot 9 \mathrm{~g}$ \\
\hline & & $\mathrm{MgCO}_{3}$ & $\mathrm{I} \cdot 5 \mathrm{~g}$ \\
\hline Choline & $450 \mathrm{mg}$ & $\mathrm{FeSO}_{4}$ & $225 \mathrm{mg}$ \\
\hline Inositol & $450 \mathrm{mg}$ & $\mathrm{Al}_{2}\left(\mathrm{SO}_{4}\right)_{3} \mathrm{~K}_{2} \mathrm{SO}_{4}$ & $\mathrm{I} 50 \mathrm{mg}$ \\
\hline$p$-Aminobenzoic acid & $150 \mathrm{mg}$ & $\mathrm{ZnSO}_{4}$ & $90 \mathrm{mg}$ \\
\hline Nicotinic acid & $37 \cdot 5 \mathrm{mg}$ & $\mathrm{MnSO}_{4}$ & $22.5 \mathrm{mg}$ \\
\hline Calcium pantothenate & $22.5 \mathrm{mg}$ & $\mathrm{CuSO}_{4}$ & $22.5 \mathrm{mg}$ \\
\hline Thiamine & $9.0 \mathrm{mg}$ & $\mathrm{NiSO}_{4}$ & $7 \cdot 5 \mathrm{mg}$ \\
\hline Pyridoxine & $5.0 \mathrm{mg}$ & $\mathrm{NaF}$ & $7.5 \mathrm{mg}$ \\
\hline Riboflavine & $4.5 \mathrm{mg}$ & $\mathrm{KBr}$ & $\mathrm{I} \cdot 8 \mathrm{mg}$ \\
\hline \multirow[t]{5}{*}{ Cyanocobalamin } & $30 \mu \mathrm{g}$ & $\mathrm{CoSO}_{4}$ & $3.75 \mathrm{mg}$ \\
\hline & & $\mathrm{Na}_{2} \mathrm{MoO}_{4}$ & $3.75 \mathrm{mg}$ \\
\hline & & $\mathrm{H}_{3} \mathrm{BO}_{3}$ & $3.75 \mathrm{mg}$ \\
\hline & & $\mathrm{KI}$ & $0.3 \mathrm{mg}$ \\
\hline & & $\mathrm{As}_{2} \mathrm{O}_{3}$ & $0.15 \mathrm{mg}$ \\
\hline
\end{tabular}

The protein-free diet is shown in Table $\mathbf{I}$. The calorie content of this diet was approximately $4.15 \mathrm{kcal} / \mathrm{g}$. The diet with the potato-protein base contained $793 \mathrm{~g}$ potato protein and $207 \mathrm{~g}$ of the protein-free diet per $\mathrm{kg}$. The gluten diet contained $730 \mathrm{~g}$ wheat gluten and $270 \mathrm{~g}$ of the protein-free diet per $\mathrm{kg}$. The two protein-rich diets thus both contained $60 \%$ protein $(\mathrm{N} \times 6 \cdot 25)$. With the aid of a dosing machine, amounts of $\mathrm{I} g$ of the two protein-containing diets were automatically weighed and folded in paper. The test animals were seventy-two weanling male Wistar rats from sixteen litters. They were trained over a period of 14 days to consume $3 \mathrm{~g}$ of the protein-rich diets within $\mathrm{I} h$, and were given each protein on alternate days. After all the protein portion had been eaten the non-protein diet was given ad lib. during the remaining $23 \mathrm{~h}$. During both the preliminary training period and the experimental period the animals were given 14 i.u. vitamin $A$ (as acetate) and 50 i.u. vitamin $D_{2}$ per day in three doses per week in arachis oil, and drinking water ad lib. Eight animals were unable to consume the $3 \mathrm{~g}$ protein portion in $\mathrm{I} h$; two of these were discarded and the remaining six were equally distributed over the experimental groups fed ad lib. on both protein-rich and protein-free diets so as to keep the groups on restricted protein rations strictly comparable.

After training, the animals were distributed among the seven experimental groups so that the total weight of each group was the same and all groups contained the same number of animals from each litter. 
For $\mathrm{I} h$ daily group $\mathrm{I}$ received $2 \mathrm{~g}$ of the potato-protein diet, group 2 received $3 \mathrm{~g}$ of the potato-protein diet, group 4 received $2 \mathrm{~g}$ of the gluten diet, and group 5 received $3 \mathrm{~g}$ of the gluten diet. Throughout the $24 \mathrm{~h}$ group 3 received the potato-protein diet ad lib. and group 6 the gluten diet ad lib.; at the same time these two groups received the non-protein diet ad lib. in a separate feeding-trough. The other groups received the non-protein diet during the remaining $23 \mathrm{~h}$ in which no gluten or potato protein was supplied. When both diets were given ad lib. the cages were divided into two compartments. The protein-rich and protein-free diets were supplied in different compartments so that any food spilt could be collected separately. All other environmental conditions were the same for the groups on restricted and unrestricted feeding. The animals of the seventh group were killed, at the end of the training period, for carcass analysis. Protein and fat were determined on a homogenate of the pooled carcasses.

Intakes of non-protein food, and for groups 3 and 6 also of protein-rich food, were determined daily. Body-weights were recorded weekly. The experiment lasted for 5 weeks. PERs and food efficiency ratios (FER) were calculated for each week and for the whole period. At the end of the experiment the rats were killed and the mean body composition for each group was determined.

The determination of the body composition of a control group at the beginning and that of the test group at the end of the experiment permitted a calculation of two other utilization figures, namely retention of calories and retention of proteins. The latter value was proposed by Shukers \& McCollum (1929) as a reliable measure for protein quality. This proceeding has also been adopted by Rerat \& Henry (1963) when they carried out their separate feeding experiments; the amount of nitrogen stored by the experimental animals and taken as a percentage of nitrogen intake was called 'Coefficient d'Utilisation Pratique de l'Azote'. In the study now presented the term practical protein utilization (PPU) is used.

\section{RESULTS}

The values for mean weight gain, food consumption and efficiency of food conversion over the whole experimental period are given in Table 2, and similar values relating to intermediate periods are presented in Figs. I-4. The results summarized in Table 2 clearly show a great difference between the growth-promoting effects of the potato-protein and the wheat-gluten diets.

The reliability of the differences was tested statistically by the Wilcoxon's distribution-free two-sample test (Siegel, 1956).

In Table 3 the computed (bilateral) significance level is given for a number of differences. With restricted protein, gain in weight was much greater on the potatoprotein diet. When protein intakes were the same the calorie intake of the groups given potato protein was higher and consequently the percentage of protein in the diet was lower. In other words, more calories per $g$ of protein were consumed in the group with the higher protein quality. Likewise the decrease of the calorie to protein ratio with increasing protein content of the diet was evident in the groups given potato or gluten. Efficiency of conversion and utilization of food were also better on the 
potato-protein diets when the results of restricted feeding are compared. With ad lib. feeding the differences in weight gain were less pronounced. With ad lib. intakes of potato protein and gluten, weight gains tended to reach optimal values. FERs as well as calorie utilization for growth hardly varied between these groups. This similarity

Table 2. Mean values for initial and final body-weight and body composition, rate of weight gain, food consumption and utilization of protein and calories for six groups of ten rats given different dietary regimens for 5 weeks

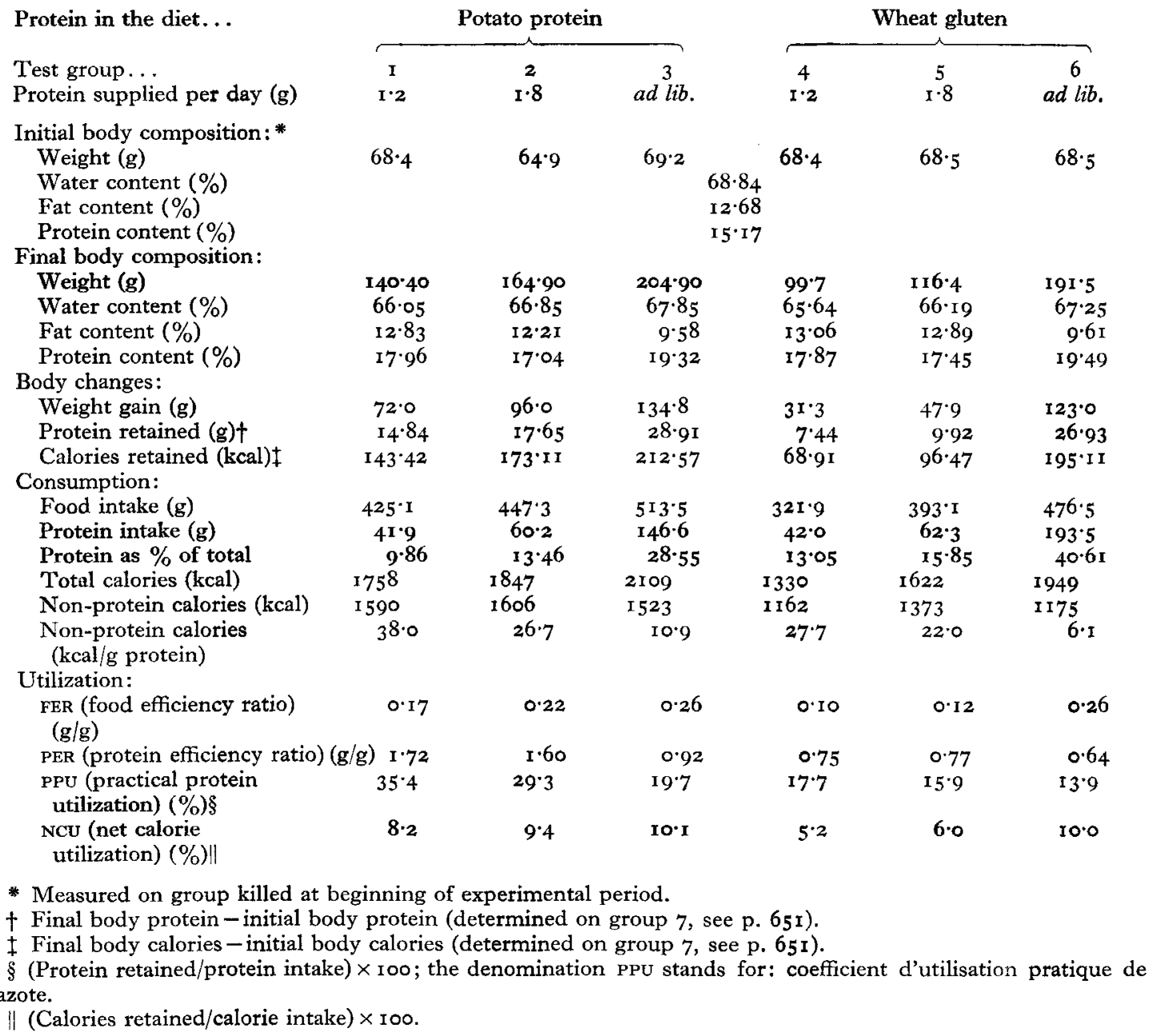

was obviously the result of a far higher protein intake in the group with the biologically inferior gluten protein at a total calorie level which was much less divergent for the two groups; in consequence, the protein content of the diet was considerably greater for the group given gluten than for that given potato protein. It is clear from the spontaneous selection of the diet of higher protein content and from the lack of increase in rate of weight gain of this group compared with that of the group given 

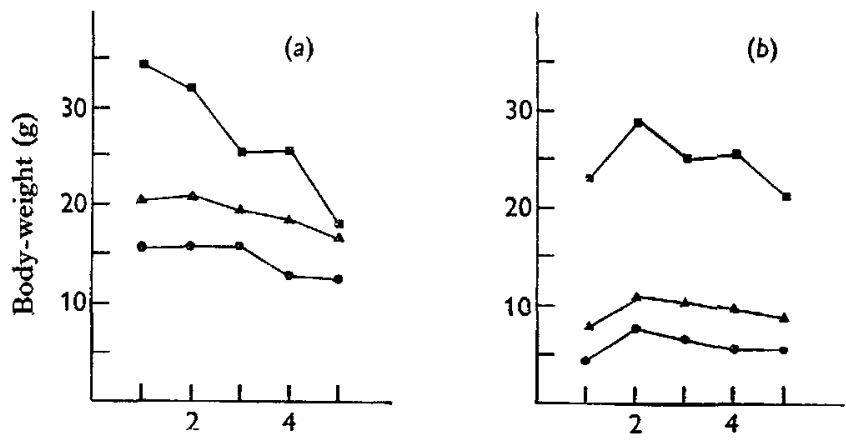

Week of experiment

Fig. I. Body-weight gain of groups of ten rats given for 5 weeks different dietary regimens. $a$, potato-protein diet; $b$, wheat-gluten diet; - $-1200 \mathrm{mg}$ protein daily; $\mathbf{\Delta}-\mathbf{\Delta}, \mathbf{1} 800 \mathrm{mg}$ protein daily; $\mathbf{\square}-$ ad lib. feeding.

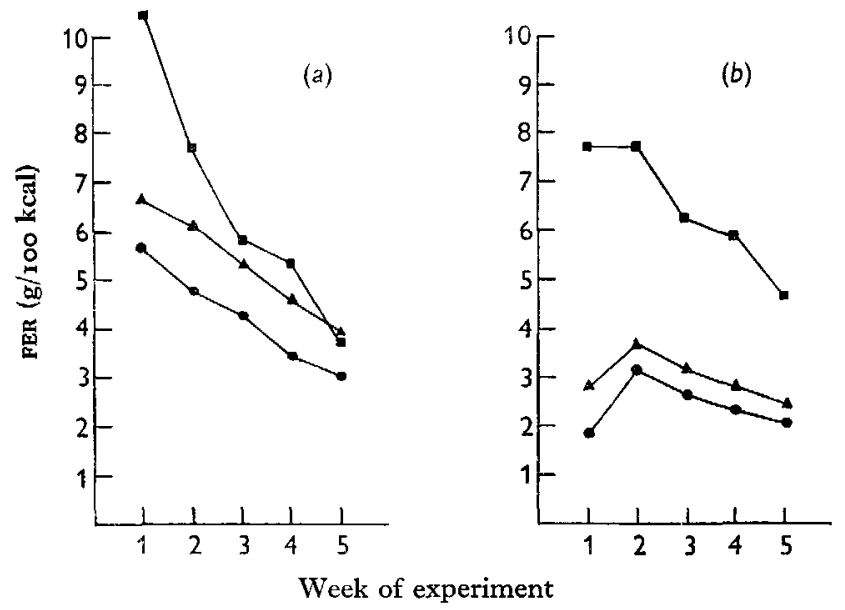

Fig. 2. Food efficiency ratio (FER) (see p. 65I) of groups of ten rats given for 5 weeks different dietary regimens. $a$, potato-protein diet; $b$, wheat-gluten diet; $-1,200 \mathrm{mg}$ protein daily; A $\boldsymbol{A}$, I $800 \mathrm{mg}$ protein daily; - ad lib. feeding.

potato protein that lower protein efficiency and utilization values would be obtained for the group given gluten.

\section{DISCUSSION}

Although the proteins and calories were given separately to groups $1,2,4$ and 5 they were more or less continuously consumed. It was noticed in the training period that the animals of these groups showed a craving for the protein when the unemptied trough with non-protein diet was withdrawn, and after ingesting the protein-rich ration they were eager to obtain the calories from which they almost exclusively ate in the first $2, \mathrm{~h}$ after the change of food. It is well known that, when proteins and calories are given together, their utilization is quite different from that when given separately, depending on the time interval between protein and calorie supply. Under our experimental conditions the interval was short because the animals consumed the two diets 

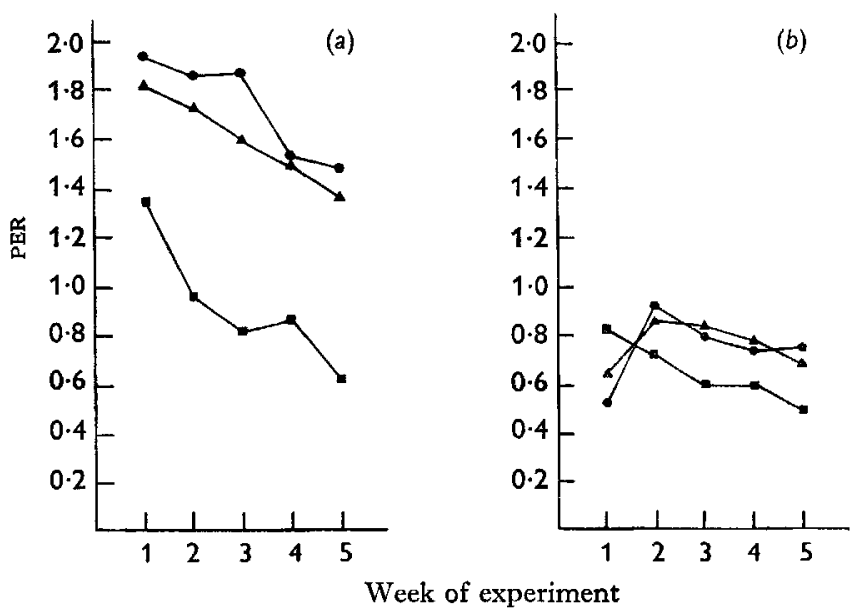

Fig. 3. Protein efficiency ratios (PER) (see p.649) of groups of ten rats given for 5 weeks different dietary regimens. $a$, potato-protein diet; $b$, wheat-gluten diet; $-0,1200 \mathrm{mg}$ protein daily; $\Delta-\Delta$, I $800 \mathrm{mg}$ protein daily; $\square-\square$, ad lib. feeding.

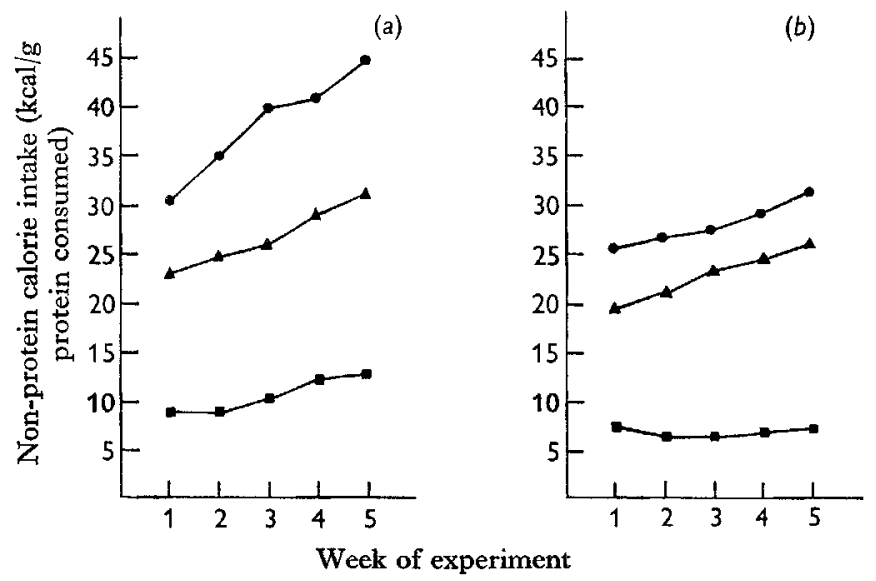

Fig. 4. Non-protein calorie intake per $\mathrm{g}$ protein consumed by groups of ten rats given for 5 weeks different dietary regimens. $a$, potato-protein diet; $b$, wheat-gluten diet; $-1,1200$ mg protein daily; $\mathbf{A}-\mathbf{\Lambda}$, I $800 \mathrm{mg}$ protein daily; $\mathbf{\square}-\mathbf{\square}$, ad lib. feeding.

Table 3. The statistical significance of differences between treatment mean values from Table 2, calculated by Wilcoxon's two-sample test

Comparison between groups

$\begin{array}{lccccl}\text { Growth } & 0.002 & <0.0001 & <0.0001 & <0.0001 & 0.05 \\ \text { Food intake } & \text { NS } & 0.0007 & <0.0001 & 0.02 & 0.09 \\ \text { FER } & 0.0005 & 0.003 & <0.001 & <0.0001 & \text { NS } \\ \text { PER } & 0.06 & \text { NS } & <0.0001 & <0.0001 & 0.003 \\ \text { Protein }(\% \text { of diet) } & <0.0001 & 0.001 & <0.0001 & 0.002 & 0.0004\end{array}$

NS, not significant. 
successively within $3 \mathrm{~h}$. These differences, whatever their nature, preclude any immediate comparison between the animals given protein and calories separately and those given them mixed. However, they have no bearing on the relationship between body-weight and total calorie intake, so that the significant statement made by French workers to the effect that body-weight completely determines total calorie intake could be checked with our results from both the separate and mixed feeding trials. This was done by plotting for each separate group the mean weekly intake of total calories against the mean of the body-weights at the beginning and end of the week. From the six groups thirty points were obtained; the relationship was curvilinear (Fig. 5). If

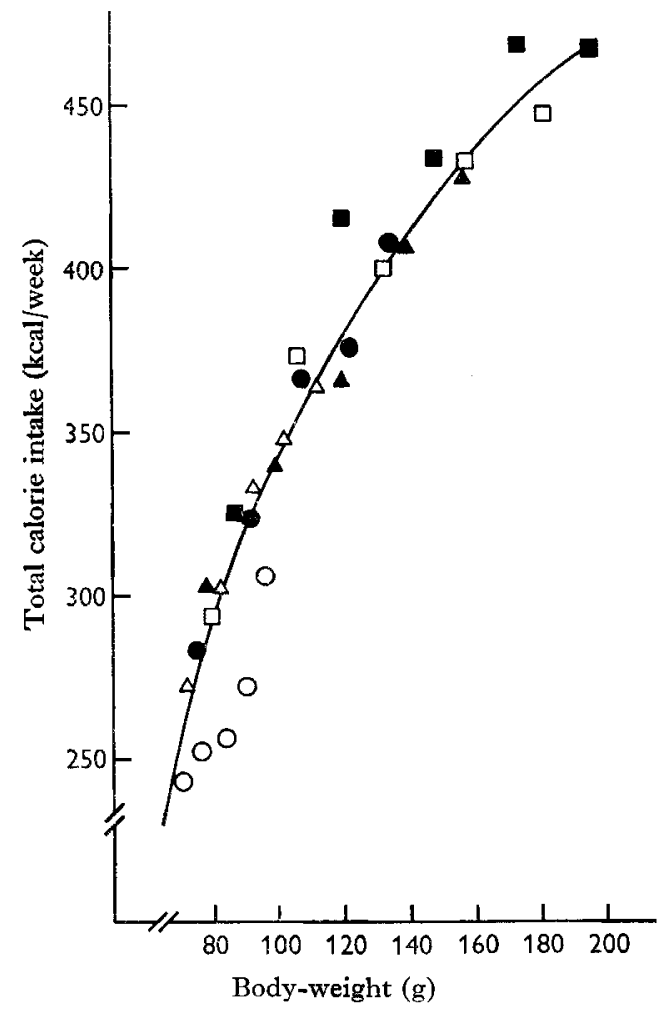

Fig. 5. Relation between body-weight and total calorie intake of groups of ten rats given for 5 weeks different dietary regimens. $-\mathrm{I} \cdot 2 \mathrm{~g}$ potato protein daily; $\boldsymbol{\Delta}, \mathrm{I} \cdot 8 \mathrm{~g}$ potato protein daily; $\square$, ad lib. feeding; $O, \mathrm{I} \cdot 2 \mathrm{~g}$ wheat gluten daily; $\triangle, \mathrm{I} \cdot 8 \mathrm{~g}$ wheat gluten daily; $\square$, ad lib. feeding.

this relationship has any significance the animals on the restricted gluten diet (intake of $1200 \mathrm{mg} /$ day) consumed fewer calories than might be predicted from their bodyweight. It is also evident that calorie intake was relatively less in the heavier animals. This might be expected from the diminishing rate of weight gain (not only relatively, but according to Fig. I also in an absolute sense) with the progress of growth. The slowing down of the optimal rate of growth has been defined as the self-inhibiting phase and mathematically treated by Brody (1945). The curve in Fig. 5 can be straightened by plotting the logarithmic values of the intakes against those of the bodyweights. To facilitate comparison the logarithms of daily intakes are plotted in Fig. 6, 
as was done by Rerat \& Henry (1963). Statistical treatment of these results revealed some highly significant correlations.

In this instance the following individual values were used instead of the mean values: the logarithmic values of the mean daily total calorie intakes in the Ist, $3^{\text {rd }}$ and $5^{\text {th }}$ experimental weeks, the logarithms of the corresponding mean body-weights and the logarithms of the protein intakes. Thus from each of the sixty animals there were three values for body-weight, calorie intake and protein consumption $(n=180)$. The following correlation coefficients were computed: for weight versus calories $r=0.864$, for weight versus protein $r=0.492$ and for calories versus protein $r=0.503$. These correlations were all highly significant. Partial correlation yiclded only one statistically significant coefficient, namely for the relation of weight to calorie intake at a constant protein intake $r=0.819$. If $C$ represents total daily calorie intake (kcal) and $W$ body-weight (g), the regression line is given by the equation

$$
\log C=0.5 \mathrm{I}+0.5^{8} \log W \text {. }
$$

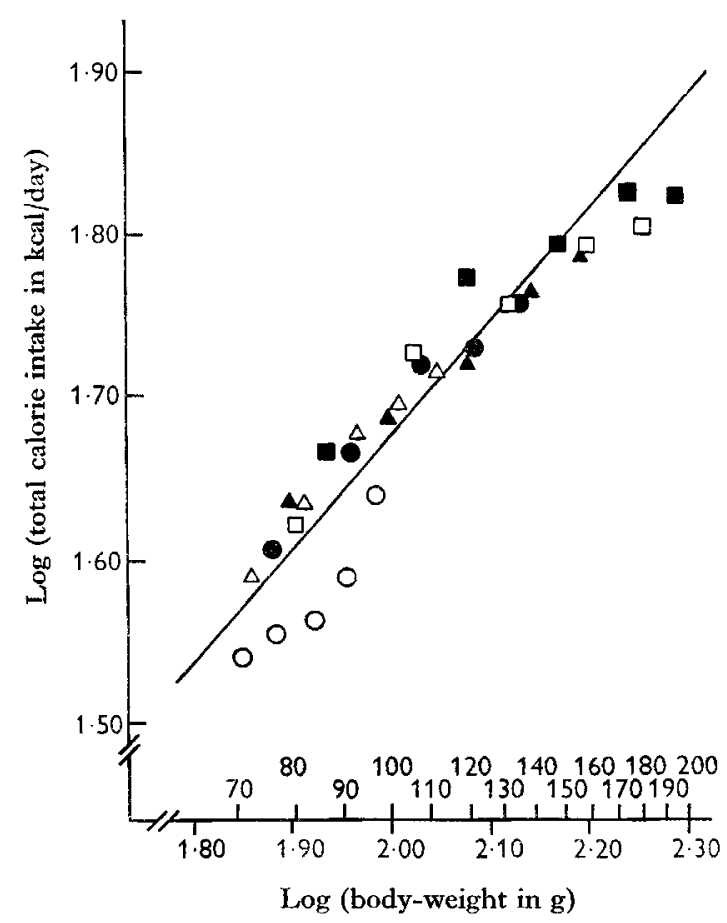

Fig. 6. Regression of total calorie intake on body-weight for groups of ten rats given for 5 weeks different dietary regimens $(\log C=0.5 \mathrm{I}+0.58 \mathrm{~W})$., $\mathrm{I} \cdot 2 \mathrm{~g}$ potato protein daily; $\Delta, \mathbf{I} \cdot \mathbf{8} \mathrm{g}$ potato protein daily; $\mathbf{\omega d}$ lib. feeding; $0, \mathbf{I} \cdot \mathbf{2} \mathrm{g}$ wheat gluten daily; $\Delta, \mathbf{I} \cdot 8 \mathrm{~g}$ wheat gluten daily; $\square$, ad lib. feeding.

The points representing the low-level gluten feeding were below the regression line presented in Fig. 6. From this figure there is a strong suggestion of a quadratic effect. The quadratic equation fitted to the logarithm runs

$$
\log C=0.216+\text { г.61 } \log W-0.245(\log W)^{2} .
$$


From this equation the decrease of the slope of the curve, equivalent to the regression coefficient of the linear equation, with increasing body-weight can easily be calculated. However, the value of the $F$ statistic is rather small $\left(F_{1}^{177}=2.583\right)$ and thus $\log C$ can better be estimated from the linear regression line. Regression equations were calculated separately for the animals fed on potato protein and on gluten in order to establish whether these differences from the regression had any significance. The following equations were obtained: for potato protein

and for gluten

$$
\log C=0.67+0.52 \log W \quad(r=0.836 ; n=90)
$$

$$
\log C=0.4 \mathrm{I}+0.6 \mathrm{I} \log W \quad(r=0.877 ; n=90) .
$$

There was a marked difference between the regression coefficients; this can be attributed to the smaller body-weights in the groups given gluten, as explained below. The slopes of the regression lines calculated by the French workers agree fairly well with the value of 0.6 found in our study, although our slopes were generally somewhat steeper. This was especially so when the French investigators included heavy animals of up to $35^{\circ} \mathrm{g}$. The explanation may be found in the fact that the calorie-weight curve (Fig. 5) may tend to flatten when maximal weights are approached. The study now presented reveals that the free intake of calories was proportional to the bodyweight raised to the power of $0 \cdot 6$. This exponent should be regarded as an approximation and has validity only for a certain body-weight range, namely from 70 to $190 \mathrm{~g}$. In this connexion attention should be drawn to the relationship between body-weight and basal metabolism described by Brody (1945); in young rats of between 50 and $100 \mathrm{~g}$ the basal metabolism seemed to vary with weight raised to the $0.84-0.9$ power, whereas in adult animals basal metabolism was proportional to body-weight raised to the power of 0.35 . This considerable amount of agreement as to the relationship between body-weight and calorie intake contrasts with the important divergence of opinion regarding the influence of protein requirement on the voluntary intake of protein. Whereas, under their experimental conditions, the French authors were unable to find a difference between the protein intake when gluten and fishmeal were supplied ad lib. and separately from non-protein calories also given $a d$ lib., the voluntary intake of potato protein in our study was far lower than that of gluten. Comparing these diets, the potato-protein diet contained $28.6 \%$ protein and the gluten diet $40.6 \%$.

The explanation of this contradiction is probably to be found in the different compositions of components used in the protein-rich food. The concentrated protein diets used by us contained $60 \%$ protein; the diets used by the French investigators contained only $38 \%$, which is less than the protein content of the diet spontaneously chosen in the trial described here, in which the gluten diet was given ad lib. In Figs. 5 and 6 , several points obtained with the gluten and potato-protein diets coincide. This suggests that, at the same body-weight, the total calorie intake was the same irrespective of the protein source. Only the protein levels differ when two such points are compared. Moreover these protein levels are well established. The standard deviations were $0.8, \mathrm{I} \cdot 4,7 \cdot 0, \mathrm{I} \cdot 3, \mathrm{I} \cdot 5$ and 4.9 and the coefficients of variation $7 \cdot 6,10 \cdot 4$, $24 \cdot 8,9 \cdot 9,9 \cdot 4$ and $12 \cdot 1 \%$ respectively for groups $I, 2,3,4,5$ and 6 . Except for group 
3 , given the potato-protein diet ad lib., the protein to calorie ratios fell within narrow limits. This fact, and the statistically significant differences between the protein levels of the various groups, support the conclusion of the French group that food intakes are regulated by energy requirements, which are in turn functions both of body-weight and of the quantity and quality of the protein.

The technique of feeding protein and calories separately to experimental animals was also successfully applied by Frost \& Sandy (1949) in their depletion-repletion experiments. They also noted that with a fixed protein supply more calories were consumed with improvement in quality of the protein; this led them to suggest that differences in appetite might be used as a criterion for evaluating protein.

For maximal growth a maximal number of calories is required. From Tables 2 and 3 it is clear that the values for weight gain and total calorie intake are very similar for group 3 (potato protein $a d$ lib.) and group 6 (gluten $a d$ lib.), as are consequently the FERs, the differences being statistically not, or with respect to weight gain scarcely $(P=0.05)$, significant, possibly also owing to the rather great variation in weight gain and the intake of total calories of the group given potato protein. To obtain maximum protein retention with the calorie intake obtained on ad lib. feeding, there is competitive utilization of dietary amino acids for synthetic and catabolic purposes. 'This is controlled by the animal's needs for protein on the one hand and the ratio of protein to non-protein calories in relation to energy requirements on the other. To meet requirements more of the biologically inferior protein, gluten, was needed. With almost equal calorie intakes, this implies that with gluten the ratios of protein to non-protein calories shifted in a direction indicating increasing combustion of protein.

The results obtained in the restricted feeding trials are also readily explained. Considering $1200 \mathrm{mg}$ of the protein as composed of a part $(x \mathrm{mg})$ of ideally balanced protein-the amount of which is determined by the quantity of the limiting amino acid present-and a part $(1200-x) \mathrm{mg}$ of non-essential protein totally lacking one essential amino acid, a portion $(x-200) \mathrm{mg}$ is available for synthesis of tissue protein. In this assumption $200 \mathrm{mg}$ is taken as the basal metabolic need of an animal weighing $70 \mathrm{~g}$. With gluten, the available portion is very small, and hence a proportionately small amount of non-protein calories is needed to supply the energy for synthesis. When r8oo mg of gluten are supplied to animals with the same basal metabolic needs, the amount available for growth is greater both absolutely and relatively, namely one and a half times the former available portion plus $100 \mathrm{mg}$ or $\left[\frac{3}{2}(x-200)+100\right] \mathrm{mg}$. With increases in the portion available for synthesis considerably more energy is needed. According to Table 2 the amount of non-protein calories consumed increased by no less than $18 \%$. This increased calorie intake sufficed to raise the weight gain by $51 \%$, while protein consumption increased by $48 \%$. As a result PER increased, notwithstanding the fact that the increased amino acid concentrations in the cellular fluids increased the risk of amino acid combustion. Potato protein is better balanced than is wheat gluten. The much greater available portion $(x-200) \mathrm{mg}$ of potato protein clearly requires more energy for tissue synthesis. According to Table 2 the amount of non-protein calories surpassed by $37 \%$ the amount needed on the comparable gluten diet. More calories imply faster growth; thus PER on equal protein intake was 
far higher in the group given potato protein. By raising the potato-protein supply to $1800 \mathrm{mg}$, even more calories were needed. But, by augmenting $x$, the relative increase of available protein, being

$$
\frac{\left(\frac{3}{2} x-200\right)-(x-200)}{x-200}=\frac{\frac{1}{2} x}{x-200},
$$

is decreasing. Therefore, when the protein supply was increased from I 200 to $1800 \mathrm{mg}$, the parallel increase in non-protein calorie intake of $\mathrm{I} \%$ for the potato-protein groups contrasted with the corresponding increase of $18 \%$ for the gluten groups.

Obviously when protein is given at this level the increased requirement of energy for tissue synthesis is partly met by the combustion of protein; with potato protein this energy can no longer be derived exclusively from the relatively small non-essential portion. As a result PER decreases with increasing protein content of the diet. Maximal PER values are obtained for high-quality proteins at much lower dietary protein levels than for inferior proteins (Osborne \& Mendel, 1920). Similar arguments can be put forward for NPU values.

When the situation from week to week was considered (Figs. I-4) decreased FER and PER were observed with the potato-protein diets. This may have been because the amino acid and calorie requirements of the growing rats increased while the protein intake was kept constant and increased consumption of non-protein calories was limited by the restricted protein retention. However, with the restricted gluten feeding there was such a delayed growth in the Ist week that basal needs could be altered only slightly. Since, with the unchanged nitrogen intake in the 2nd week, the total calorie intake increased slightly, this calorie supply obviously increasingly exceeded the calorie requirements. Consequently the increased weight gain observed with an unchanged protein intake implies a rise in PER in the and week. Meanwhile the basal requirements were perceptibly increased and a decline of PER similar to that described for the potato protein was noticed in the further weeks. From the intersections of the PER curves in Fig. $3 b$ for the Ist and 2nd weeks it can be concluded that results from short-term and from long-term trials may differ considerably. As a consequence the results of experiments of short duration should be interpreted with great care and may differ from those obtained in long-term experiments. For instance, on the basis of a level of $1200 \mathrm{mg}$ protein/day the PER calculated for the potato-protein diet is 3.7 times as great as the PER for the gluten diet, and in the and week the factor was reduced to $2 \cdot 0$. If the close relationship between PER and PPU is taken into account, it is quite possible that the same holds true for PPU, and also for NPU, determinations in experiments of short duration.

The carcass analyses were done to obtain information on the influence of the diet on the composition of the newly synthesized tissues and were carried out on pooled samples, making a statistical treatment of the calculated protein retentions impossible. However, PPU values have been calculated for comparison with PER. Generally speaking, the PPU method should give more reliable results than the PER because changes in body composition are taken into account. On the other hand, it is claimed that the NPU method gives utilization values for growth only, a correction being made for the protein used for maintenance. The differences between the three methods are 
more clearly seen when expressed algebraically. Let $a$ and $n_{1}$ respectively denote the body-weight and the body nitrogen content of the nitrogen-deficient group included in the NPU method, $b, n_{2}$ and $c, n_{3}$ the corresponding values of the test group at the start and at the end of the experiment, and $N$ the amount of nitrogen consumed by the test group. When no distinction is made between initial and final body nitrogen content ( $n_{2}$ being equal to $n_{3}$ ), then PER can be described:

$$
\begin{aligned}
& \text { PER }=\frac{c-b}{6 \cdot 25 N}=\frac{\left(c n_{3}-b n_{2}\right) / n_{2}}{6 \cdot 25 N}=\frac{1}{625 n_{2}} \frac{\operatorname{IOO}\left(c n_{3}-b n_{2}\right)}{N}, \\
& \mathrm{PPU}=\frac{\mathrm{IOO}\left(c n_{3}-b n_{2}\right)}{N}, \\
& \mathrm{NPU}=\frac{\mathrm{IOO}\left(c n_{3}-b n_{2}\right)+\operatorname{IOO}\left(b n_{2}-a n_{1}\right)}{N}=\frac{\operatorname{IOO}\left(c n_{3}-b n_{2}\right)}{N}+\frac{C}{N} .
\end{aligned}
$$

The essential difference between (I) and (2) is made less distinct by assuming that the bodies contain the same proportion of nitrogen at the start and end of the experiment. This simplification is one of the drawbacks of the PER method. In practice, however, a fairly good correlation may be expected between the results of both methods. The difference between (2) and (3) consists in the correction factor for maintenance requirements $C / N$. When separate feeding was applied to both the PPU and the NPU methods the term $C / N$ was exactly the same when two different proteins were tested at the same fixed protein level, as in our restricted feeding experiments. Under these conditions the NPU values must closely follow the trends in the PPU. The separate feeding procedure has some advantages when applied to the PER method. Increasing feed intake and thus increasing protein intake cause the PER values to rise in mixed feeding experiments (Stewart, Hensley \& Peters, 1943). Therefore, the difference obtained when a protein with a high and one with a low biological value are compared must be accentuated since much more of the high-quality protein diet is eaten in general. With separate feeding the protein consumption is restricted and kept the same for the different proteins under test. But the main advantage of the separate feeding procedure, applicable to all three methods, is that the intake of the test material is quantitatively fixed at any standardized arbitrary protein level, the protein to calorie ratio assuming a value of distinct physiological significance. Standardization of a protein level in mixed feeding means that the protein to calorie ratio is not only arbitrary but may prove to be more favourable for one test protein than for another. Moreover the amount of protein consumed differs in the test groups compared. An additional advantage is that separate feeding experiments are easy to conduct, especially when the protein portions can be prepared mechanically. If the animals are well trained and fed at a low protein level (I $200 \mathrm{mg} /$ day or less) control and weighing of uneaten food is almost superfluous, and only the animals need to be weighed. It is claimed by Abraham \& Peretianu ( 1963 ) that the variance is less when the method of restricted and separate protein feeding is applied than when the classical method of mixed feeding is used. However, this could not be proved with the present experiment. The standard deviations of PERs when the protein level was low were $10 . \mathrm{I}$ and $\mathrm{I} 2.0 \%$ for the potatoprotein and gluten groups respectively. With the intermediate protein level, the cor- 
responding deviations were $\mathrm{I}_{3} .4$ and $10 \%$. With ad lib. protein feeding a large deviation was found for potato protein, namely $22.7 \%$, and a fairly normal one for gluten, namely $12 \cdot 2 \%$. These coefficients of variation were certainly not smaller than those obtained in previous studies with the mixed feeding procedure carried out under strictly comparable environmental and other experimental conditions on rye and barley protein. In three experiments with rye the coefficients of variation of PER were $10.4,5.5$ and $x 4.8 \%$; in three experiments with barley the coefficients of variation were $8 \cdot 3,7 \cdot 6$ and $8 \cdot 1 \%$.

Table 4. Ratio of the quality of potato protein to that of wheat gluten assessed from weight gain, non-protein calories (NPC) consumed per $g$ protein, food efficiency ratio (FER), protein efficiency ratio (PER), net calorie utilization (NCU) for growth and practical protein utilization (PPU) (see p. 65I)

$\begin{array}{ccccccc}\begin{array}{c}\text { Daily protcin } \\ \text { allowance (mg) }\end{array} & \begin{array}{c}\text { Weight } \\ \text { gain (g) }\end{array} & \text { NPC } & \text { FER } & \text { PER } & \text { NCU } & \text { PPU } \\ \text { I200 } & 2 \cdot 30 & \mathrm{I} \cdot 37 & \mathrm{I} \cdot 74 & 2 \cdot 3 \mathrm{I} & \mathrm{I} \cdot 58 & \mathbf{2} \cdot 00 \\ \mathrm{I} 800 & 2 \cdot 00 & \mathrm{I} \cdot 2 \mathrm{I} & \mathrm{I} \cdot 76 & \mathbf{2} \cdot 07 & \mathrm{I} \cdot 57 & \mathrm{I} \cdot 89 \\ \text { Ad lib. } & \mathrm{I} \cdot \mathrm{I0} & \mathrm{I} \cdot 70 & \mathrm{I} \cdot 02 & \mathrm{I} \cdot 45 & \mathrm{I} \cdot 0 \mathrm{I} & \mathrm{I} \cdot 42\end{array}$

Separate feeding does not overcome the drawback that the results of the PER, PPU and NPU methods, like those of most biological protein assays, depend on the dietary protein level. The extent of dependence found in our experiment is shown in Table 4 . A further drawback is that not all protein materials lend themselves to the preparation of a concentrated protein diet.

\section{REFERENCES}

Abraham, J., Calet, C., Rerat, A. \& Jacquot, R. (196r). C. r. hebd. Séanc. Acad. Sci., Paris 253, 2768. Abraham, J. \& Peretianu, J. (1963). Annls Biol. anim. Biochim. Biophys. 3, Suppl. no. I, p. 97.

Bigwood, E. J. (196́5). Biblthca 'Nutr. Dieta' 7, 82.

Brody, S. (1945). Bioenergetics and Growth. New York: Reinhold Publishing Corp.

Calct, C., Jouandet, C. \& Baratou, J. (I96̆). Annls Biol. anim. Biochim. Biophys. 1, 5.

Frost, D. V. \& Sandy, H. R. (1949). F. Nutr. 39, 427.

Osborne, T. B. \& Mendel, L. B. (I920). F. biol. Chem. 41, 275.

Rerat, A. \& Henry, Y. (1963). Annls Biol. anim. Biochim. Biophys. 3, Suppl. no. 1, p. 8 I.

Shukers, C. F. \& McCollum, E. V. (1 929). Unpublished data quoted in McCollum, E. V. \& Simmonds, N. (1929), The Newer Knowledge of Nutrition, 4th ed., p. 82. New York: McMillan Co.

Siegel, S. (1956). Nonparametric Statistics for the Behavioral Sciences. New York: McGraw-Hill Book Company Inc.

Stewart, R. A., Hensley, G. W. \& Peters, F. N. Jr (1943). F. Nutr. 26, 5 I9. 